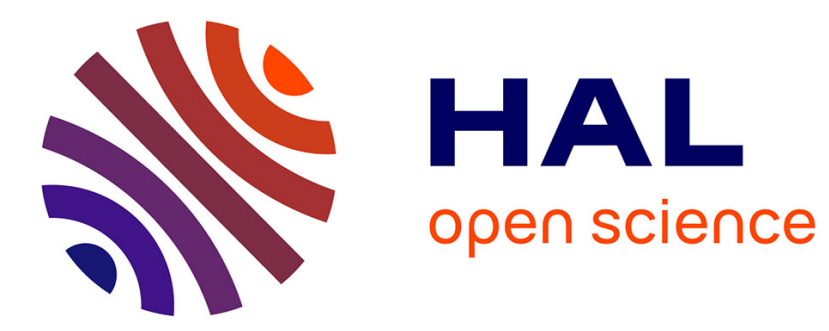

\title{
Intercalation behavior of barium phenylphosphonate
}

\author{
L. Beneš, K. Melánová, J. Svoboda, V. Zima
}

\section{To cite this version:}

L. Beneš, K. Melánová, J. Svoboda, V. Zima. Intercalation behavior of barium phenylphosphonate. Journal of Physics and Chemistry of Solids, 2010, 71 (4), pp.530. 10.1016/j.jpcs.2009.12.029 . hal00628279

\section{HAL Id: hal-00628279 \\ https://hal.science/hal-00628279}

Submitted on 1 Oct 2011

HAL is a multi-disciplinary open access archive for the deposit and dissemination of scientific research documents, whether they are published or not. The documents may come from teaching and research institutions in France or abroad, or from public or private research centers.
L'archive ouverte pluridisciplinaire HAL, est destinée au dépôt et à la diffusion de documents scientifiques de niveau recherche, publiés ou non, émanant des établissements d'enseignement et de recherche français ou étrangers, des laboratoires publics ou privés. 


\section{Author's Accepted Manuscript}

Intercalation behavior of barium phenylphosphonate

L. Beneš, K. Melánová, J. Svoboda, V. Zima

PII: $\quad$ S0022-3697(09)00371-0

DOI:

doi:10.1016/j.jpcs.2009.12.029

Reference:

PCS 6017

To appear in: $\quad$ Journal of Physics and

Chemistry of Solids

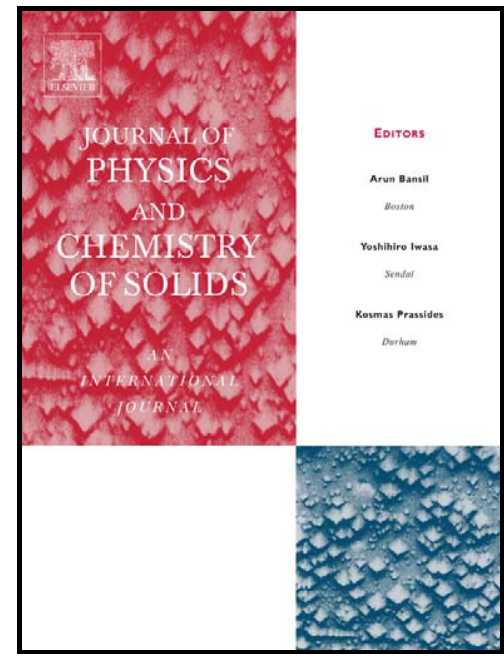

www.elsevier.com/locate/jpcs

Received date: $\quad 4$ May 2009

Revised date: $\quad 21$ October 2009

Accepted date: $\quad 3$ November 2009

Cite this article as: L. Beně̌, K. Melánová, J. Svoboda and V. Zima, Intercalation behavior of barium phenylphosphonate, Journal of Physics and Chemistry of Solids, doi:10.1016/j.jpcs.2009.12.029

This is a PDF file of an unedited manuscript that has been accepted for publication. As a service to our customers we are providing this early version of the manuscript. The manuscript will undergo copyediting, typesetting, and review of the resulting galley proof before it is published in its final citable form. Please note that during the production process errors may be discovered which could affect the content, and all legal disclaimers that apply to the journal pertain. 


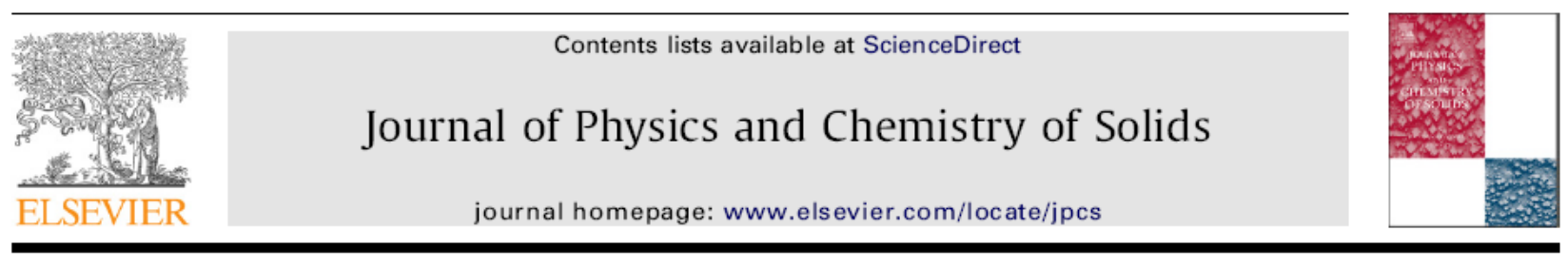

\title{
Intercalation behavior of barium phenylphosphonate
}

\author{
L. Beneš ${ }^{1 \$ *}$, K. Melánová ${ }^{2 \$}$, J. Svoboda $^{2 \$}$, V. Zima ${ }^{2 \$}$ \\ ${ }^{l}$ University of Pardubice, Faculty of Chemical Technology, Studentská 95, 53210 Pardubice,Czech Republic \\ ${ }^{2}$ Institute of Macromolecular Chemistry AS CR, v.v.i., Heyrovský Sq. 2, 16206, Prague 6, Czech Republic
}

\begin{abstract}
The dependence of basal spacing and water content of $\mathrm{BaC}_{6} \mathrm{H}_{5} \mathrm{PO}_{3} \cdot x \mathrm{H}_{2} \mathrm{O}$ on the relative humidity was studied. Intercalates of 1-alkylamines $\left(\mathrm{C}_{2}-\mathrm{C}_{10}\right)$ and 1-alkanols $\left(\mathrm{C}_{3}-\mathrm{C}_{10}\right)$ were prepared from barium phenylphosphonate dihydrate and also from anhydrous host and characterized by powder X-ray diffraction and thermogravimetric analysis. The intercalates of alkanols and alkylamines prepared from dihydrate are quite stable at ambient conditions and contain one guest molecule per formula unit. The guest molecules are probably arranged in monomolecular way and are perpendicular to the host layers in the case of amines or tilted to the host layers at an angle of about $80^{\circ}$ in the case of alkanols. The intercalates prepared from anhydrous host are unstable and their basal spacings indicate parallel arrangement of the guests chains. Formation of mixed intercalates was not observed when barium phenylphosphonate dihydrate was contacted with a mixture of alkanols or amines.
\end{abstract}

Keywords: A. Inorganic compounds; A. Organic compounds; C. X-ray diffraction

\section{Article history}

Received: May 4, 2009

Received in revised form: Oct.21, 2009

\section{Accepted:Nov.3, 2009}

\section{Introduction}

Metal organophosphonates belong to a group of inorganicorganic hybrid compounds which have received much attention with the aim to obtain novel materials with interesting properties. Among phosphonates of the alkalineearth metal, the structure of hydrogen phenylphosphonates $\mathrm{M}\left(\mathrm{C}_{6} \mathrm{H}_{5} \mathrm{PO}_{3} \mathrm{H}\right)_{2} \quad(\mathrm{M}=\mathrm{Ca}, \mathrm{Sr}, \mathrm{Ba})$ were described [1-3]. The intercalations of alkylamines and alkyldiamines into calcium hydrogen phenylphosphonate $[4,5]$ and barium hydrogen phenylphosphonate $[6,7]$ were studied. The intercalations were interpreted as acid-base solid-state reactions where the basal spacings of the intercalates formed increase linearly with increasing guest chain length.
Recently, we have found that compounds with various metal/phosphorus $\mathrm{M} / \mathrm{P}$ ratios $(\mathrm{M}=\mathrm{Ca}, \mathrm{Sr}, \mathrm{Ba})$ are formed in dependence on the acidity of the reaction medium. New compounds with general formula $\mathrm{M}\left(\mathrm{C}_{6} \mathrm{H}_{5} \mathrm{PO}_{3}\right) \cdot 2 \mathrm{H}_{2} \mathrm{O}(\mathrm{M}=\mathrm{Ca}$, $\mathrm{Sr}, \mathrm{Ba})$ were prepared and characterized [8-10]. Even the determination of their structure was not possible so far, the powder X-ray patterns indicate that these compounds are layered and therefore can undergo intercalation. In this paper, we describe the intercalation of alkylamines and alkanols into barium phenylphosphonate dihydrate $\mathrm{BaC}_{6} \mathrm{H}_{5} \mathrm{PO}_{3} \cdot 2 \mathrm{H}_{2} \mathrm{O}$ and into its anhydrous form.

\section{Experimental}

The host material, $\mathrm{BaC}_{6} \mathrm{H}_{5} \mathrm{PO}_{3} \cdot 2 \mathrm{H}_{2} \mathrm{O}$, was prepared by precipitation from barium salt and phenylphosphonic acid solutions with $\mathrm{pH}$ adjusted to 8.5 [10]. The guests were obtained from Fluka or Aldrich and were used as received. All aliphatic amines were intercalated by stirring a suspension of $\mathrm{BaC}_{6} \mathrm{H}_{5} \mathrm{PO}_{3} \cdot 2 \mathrm{H}_{2} \mathrm{O}(0.1 \mathrm{~g})$ in $8 \mathrm{ml}$ of corresponding amine at room temperature (in the case of ethylamine at $0^{\circ} \mathrm{C}$ ) for two days. The intercalates of alcohols were prepared by a

*Corresponding author. Tel.: +420466036146; fax: +420466036011.

E-mail address: ludvik.benes@upce.cz

${ }^{\$}$ Present address: Joint Laboratory of Solid State Chemistry, Studentská 95, 53210 Pardubice, Czech Republic 
solvothermal treatment of a suspension of $\mathrm{BaC}_{6} \mathrm{H}_{5} \mathrm{PO}_{3} \cdot 2 \mathrm{H}_{2} \mathrm{O}$ $(0.1 \mathrm{~g})$ in $9 \mathrm{ml}$ of corresponding alcohol in a Teflon-lined 23$\mathrm{ml}$ Parr acid digestion bomb which was heated under autogenous pressure at $160^{\circ} \mathrm{C}$ for 16 hours.

Anhydrous barium phenylphosphonate was prepared by heating of the dihydrate at $250^{\circ} \mathrm{C}$ for 1 hour. Amines and alkanols were intercalated by stirring a suspension of $\mathrm{BaC}_{6} \mathrm{H}_{5} \mathrm{PO}_{3}(0.1 \mathrm{~g})$ in $8 \mathrm{ml}$ of the corresponding guest at room temperature for 2 days.

Samples used for XRD measurements contained small amounts of the free liquid guest and were covered with a protection foil. Samples for the TG measurements were dried by evaporation of the unintercalated guest in the evacuated ampoule.

Powder X-ray diffraction data were obtained with a D8-Advance diffractometer (Bruker AXS, Germany) with Bragg-Brentano - • geometry $(40 \mathrm{kV}, 40 \mathrm{~mA})$ using $\mathrm{CuK}$ radiation with secondary graphite monochromator. The diffraction angles were measured at room temperature from 2 to $37^{\circ}$ (2) in $0.025^{\circ}$ steps with a counting time of $2 \mathrm{~s}$ per step.

The thermogravimetric measurements were carried out in air between 30 and $960^{\circ} \mathrm{C}$ at a heating rate of $5^{\circ} \mathrm{C} \mathrm{min}^{-1}$.

\section{Results and Discussion}

The barium phenylphosphonate host was prepared by precipitation in a moderately basic environment. It was found that the basal spacing of the freshly precipitated wet compound $(14.85 \AA)$ differs from the value reported for barium phenylphosphonate dihydrate (13.4 ̊) [10]. The dependence of the basal spacing and water content on the relative humidity $(\mathrm{RH})$ is shown in Figure 1 . The phase with basal spacing of $14.85 \AA$ exists only in contact with parent solution and cannot be isolated and the water content cannot be determined. The phase with basal spacing of about $13.78 \AA$ is stable between 33 and $98 \% \mathrm{RH}$ and contains about 2.75 water molecule per formula unit. The phase with basal spacing of $13.30 \AA$ described previously as a dihydrate [10] is formed between 11 and 22\% RH. The barium phenylphosphonate monohydrate with basal spacing of $14.22 \AA$ can be prepared by storing the sample over phosphorus pentoxide. It cannot be prepared by thermal dehydration because all water molecules are released in one step. Anhydrous barium phenylphosphonate is formed by thermal dehydration at $250^{\circ} \mathrm{C}$ and its basal spacing is $15.39 \AA$. Anomalous increase of basal spacing when going from dihydrate to monohydrate and anhydrous compound could be probably caused by changing the hydrogen bond system in the case of monohydrate and reorganization of the layer structure in the case of anhydrous compound.

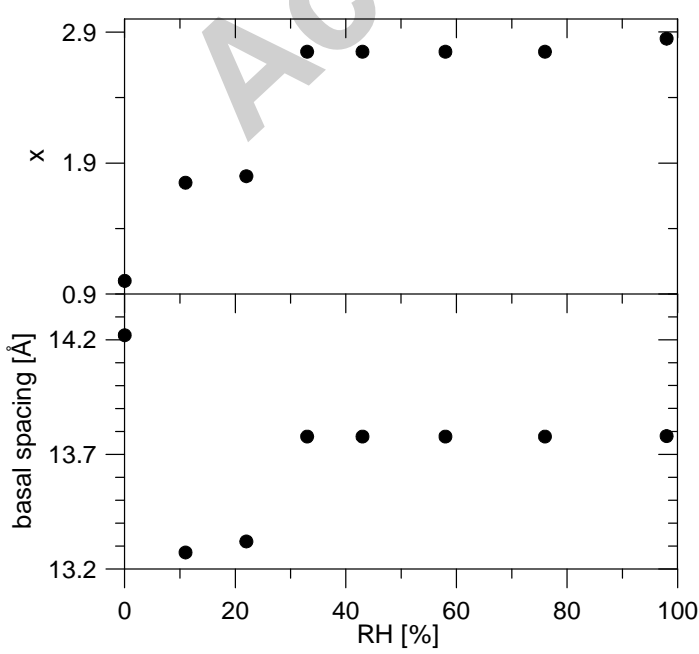

Fig. 1. The dependence of basal spacing and water content $x$ in the $\mathrm{BaC}_{6} \mathrm{H}_{5} \mathrm{PO}_{3} \cdot x \mathrm{H}_{2} \mathrm{O}$ on relative humidity $(\mathrm{RH})$.

\subsection{Intercalation into barium phenylphosphonate dihydrate}

In contrast to amines, which can be easily intercalated at room temperature, alkanols must be intercalated at elevated temperature. Intercalates of all alkanols studied were prepared by solvothermal treatment at $160^{\circ} \mathrm{C}$. The alkanol intercalates of can also be prepared by heating in microwave field in a way described previously $[11,12]$, except the propanol and butanol ones probably due to their low boiling point.

All the intercalates prepared are white crystalline powders. The diffractograms of the intercalates contain a series of sharp basal reflections (see Figure 2a, c). The alkanol intercalates are quite stable in air. For example, the butanol intercalate can be isolated either by drying in evacuated ampoule or by washing with toluene. When the dry intercalate is exposed to ambient air (about 30\% RH), a peak of parent $\mathrm{BaC}_{6} \mathrm{H}_{5} \mathrm{PO}_{3} \cdot 2 \mathrm{H}_{2} \mathrm{O}$ slowly appears in the diffractogram. The stability of the intercalates decreases with increasing chain length, phases with lower basal spacing appear during washing the intercalates with toluene. The amine intercalates are less stable than the intercalates of alkanols; they decomposes during washing with toluene or hexane and new phases with lower basal spacings were sometimes formed during the drying in an evacuated ampoule. Therefore, the samples for thermogravimetric analyses were carefully dried and their basal spacings were checked to confirm that they are the same as those of the intercalates with a small excess of the guest.

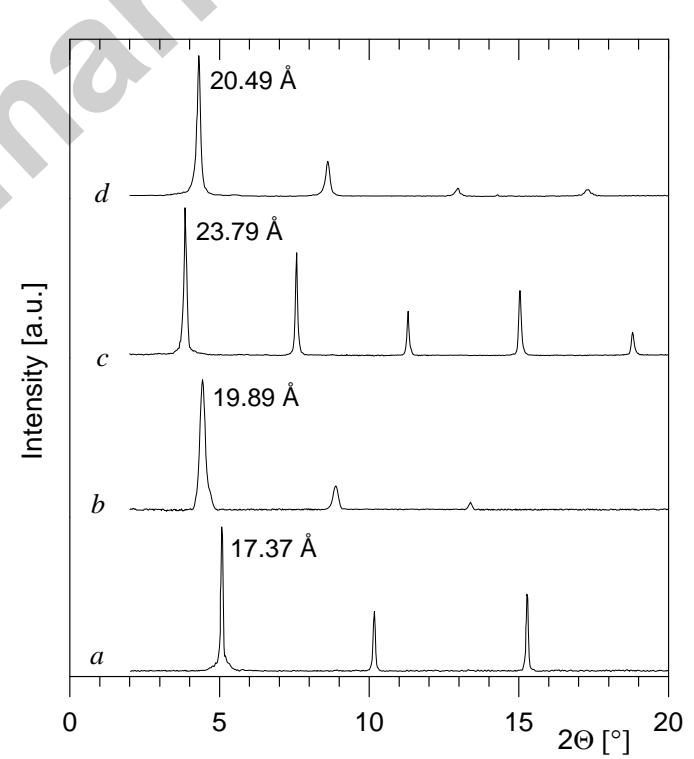

Fig. 2. The diffractograms of pentanol intercalates prepared from dihydrate (a) and from anhydrous (b) host; and octylamine intercalates prepared from dihydrate (c) and from anhydrous (d) host.

On heating, all the intercalates lose weight in two steps. As an example, the thermogravimetric curves of the intercalates with butanol and pentylamine are shown in Figure 3. In the case of the butanol intercalate, the first weight loss of $19.5 \%$ is in the temperature range $100-260^{\circ} \mathrm{C}$, the second one of roughly $18.5 \%$ occurs from 400 to $520^{\circ} \mathrm{C}$. Thus, the first weight loss corresponds to the release of one molecule of 
butanol from $\mathrm{BaC}_{6} \mathrm{H}_{5} \mathrm{PO}_{3} \cdot 0.95 \mathrm{C}_{4} \mathrm{H}_{9} \mathrm{OH}$ (calculated $19.4 \%$ ), the second loss of weight is due to the decomposition of the phenylphosphonate group (calculated $19.0 \%$ ). The product of heating to $950^{\circ} \mathrm{C}$ is $\mathrm{Ba}_{2} \mathrm{P}_{2} \mathrm{O}_{7}$, as confirmed by powder $\mathrm{X}$-ray diffraction (PDF No. 83-0990) [13]. Similarly, in the case of the pentylamine intercalate, the first weight loss of $22.5 \%$ corresponds to the release of one amine molecule from $\mathrm{BaC}_{6} \mathrm{H}_{5} \mathrm{PO}_{3} \cdot \mathrm{C}_{5} \mathrm{H}_{11} \mathrm{NH}_{2}$ (calculated $22.9 \%$ ). The second weight loss (18\%) corresponds to the decomposition of the phenylphosphonate group (calculated $18.2 \%$ ). On the basis of TGA results for the intercalates of other alkanols (propanol, pentanol, hexanol) and amines (ethylamine, propylamine, butylamine, and hexylamine) we suppose that the intercalates contain one guest molecule per $\mathrm{BaC}_{6} \mathrm{H}_{5} \mathrm{PO}_{3}$ and do not contain any water.

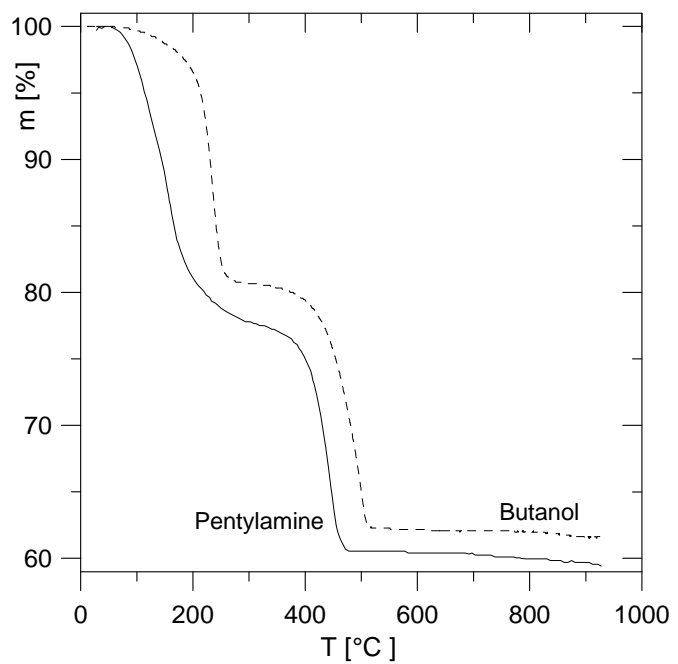

Fig. 3. Thermogravimetric curves of the butanol and pentylamine intercalates.

The dependence of the basal spacing on the number of carbon atoms in the guest chain is given in Figure 4. The dependence is linear with the slope of 1.29 and 1.26 for amines and alkanols intercalates, respectively. It means that the guest molecules are probably arranged in a monomolecular way and are perpendicular or nearly perpendicular in the case of alkanols to the host layers. It is surprising that the intercalates of amines have the basal spacing by about $2.5 \AA$ higher than the intercalates of alkanols with the same number of carbon atoms.

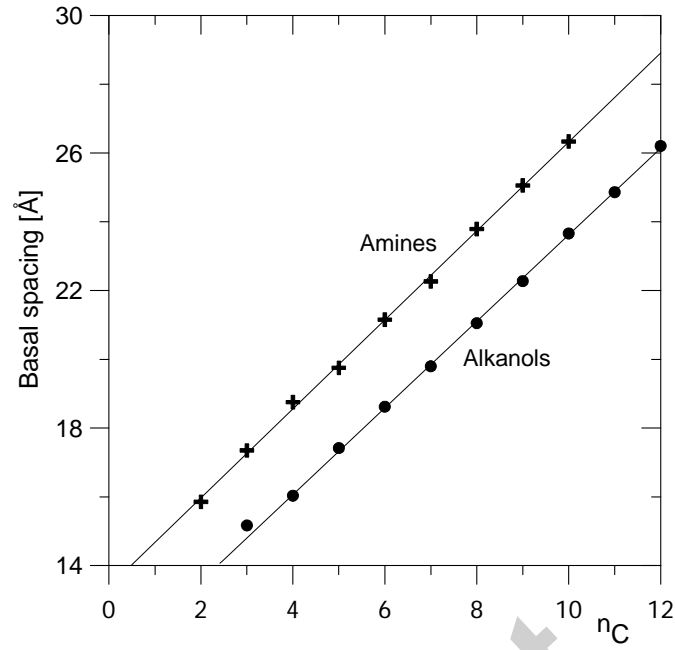

Fig. 4. The dependence of basal spacing on the number of carbon atoms in the guest chain $n_{\mathrm{c}}$ for the intercalates prepared from barium phenylphosphonate dihydrate.

To determine how the aliphatic guest molecules with different chain lengths compete in the interlayer space of the host, we studied mixed intercalates of $\mathrm{BaC}_{6} \mathrm{H}_{5} \mathrm{PO}_{3} \cdot 2 \mathrm{H}_{2} \mathrm{O}$ containing two different amines or two different alkanols. The preparation was similar as in the case of the intercalation of pure amines or alkanols that is the reaction of the barium phenylphosphonate dihydrate with a mixture of amines at room temperature and with a mixture of alkanols at $160^{\circ} \mathrm{C}$. The dependences of basal spacings of the intercalates formed on the composition of the guest mixtures are shown in Figure 5. No new phase containing both amines was observed, only the intercalates of either butylamine or octylamine were formed. Similar results were obtained in the case of exposition of barium phenylphosphonate dihydrate to the mixture of butanol and octanol. The fact that mixed intercalates are not formed supported our suggestion of monomolecular arrangement of the guest molecules in the interlayer space.

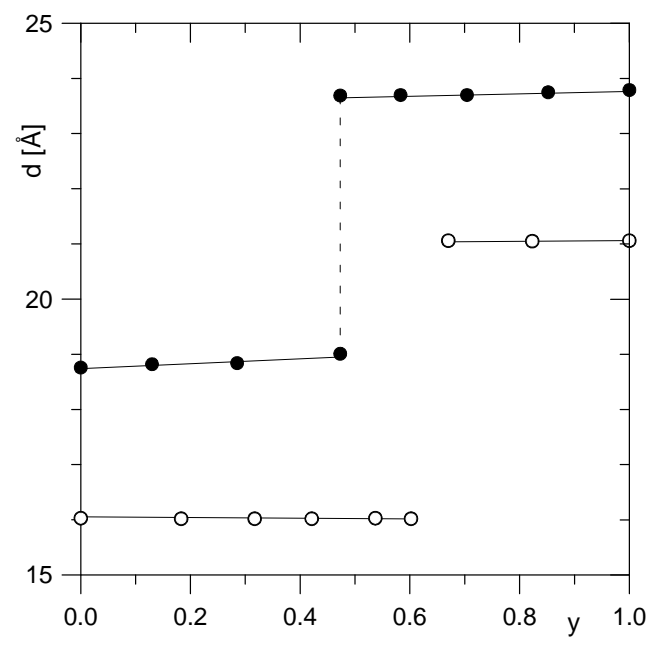

Fig. 5. The dependence of basal spacing of the intercalates formed on the molar fraction of the guest with longer chain $y$ in the liquid guest mixture: $\bullet$ butylamine - octylamine, $\bullet$ butanol - octanol. 
3.2 Intercalation into anhydrous $\mathrm{BaC}_{6} \mathrm{H}_{5} \mathrm{PO}_{3}$

Both aliphatic amines and alkanols can be intercalated into anhydrous barium phenylphosphonate at room temperature. Again, a series of sharp basal reflections were observed in the powder X-ray patterns of the intercalates prepared (see Figure $2 \mathrm{~b}, \mathrm{~d})$. The intercalates are less stable than the corresponding intercalates prepared from the dihydrate and loses the guest during washing with toluene or hexane. Only the intercalates of butylamine, pentylamine, hexylamine, pentanol and hexanol can be dried in an evacuated ampoule and the guest content can be determined. On heating, the intercalates lose weight in two steps. The first weight loss up to about $300^{\circ} \mathrm{C}$ corresponds to the release of roughly half molecule of the guest per formula unit; the second one is due to the decomposition of the phenylphosphonate. The product of heating to $950^{\circ} \mathrm{C}$ is $\mathrm{Ba}_{2} \mathrm{P}_{2} \mathrm{O}_{7}$, as confirmed by powder X-ray diffraction (PDF No. 83-0990) [13].

Basal spacings of the intercalates prepared from the anhydrous host are markedly different from the intercalates prepared from the dihydrate. Basal spacings of the alkanol intercalates are in the range from 19.6 to $20.2 \AA$ irrespectively to the chain length. The basal spacing of these intercalates is about $4.5 \AA$ higher than that of anhydrous barium phenylphosphonate (15.4 $\AA$ ) so we can deduce that the alkanol molecules are probably arranged parallel to the host layers. The basal spacings of the intercalates of shorter amines are in the range 19.7-20.6 $\AA$ and the arrangement of the guest molecules can be similar as in the case of the alkanol intercalates. The basal spacings of the intercalates of nonylamine, decylamine and dodecylamine are higher than 24 $\AA$. That is, the interlayer distance is about double of that observed for shorter amine intercalates. It can be probably caused by a bimolecular arrangement of the guest molecules which are parallel to the host layers. Similar arrangement of the guest molecules was observed for vanadyl phosphate intercalates with poly(ethylene glycols) [14].

\section{Acknowledgement}

This work was supported by the Czech Science Foundation (Project No. GA 203/08/0208), the Academy of Sciences of the Czech Republic (AV0Z40500505) and the Ministry of Education, Youth and Sports of the Czech Republic (MSM 0021627501).

\section{References}

[1] A. H. Mahmoudkani, V. Langer, Solid State Sci. 3 (2001) 519-525.

[2] A. H. Mahmoudkani, V. Langer, L. Smr ok, Solid State Sci. 4 (2002) 873-878.

[3] D. M. Poojary, B. Zhang, A. Cabeza, M. A. G. Aranda, S. Bruque, A. Clearfield, J. Mater. Chem. 6 (1996) 639-644.

[4] C. B. A. Lima, C. Airoldi, Solid State Sci. 4 (2002) 1321 1329.

[5] A. M. Lazarin, C. Airoldi, Thermochimica Acta 437 (2005) 114-120.

[6] A. M. Lazarin, C. Airoldi, J. Incl. Phenom. 51 (2005) 3340.

[7] A. M. Lazarin, I. S. Lima, J. A. Simoni, C. Airoldi, J. Mater. Res. 21 (2006) 2191-2197.

[8] J. Svoboda, V. Zima, L. Beneš, K. Melánová, M. Vl ek, Inorg. Chem. 44 (2005) 9968-9976.

[9] V. Zima, J. Svoboda, L. Beneš, K. Melánová, M. Trchová, Solid State Sci. 8 (2006) 1380-1385.

[10] J. Svoboda, V. Zima, L. Beneš, K. Melánová, M. V1 ek, M. Trchová, J . Phys. Chem. Solids 69 (2008) 1439-1443.

[11] U. Costantino, R. Vivani, V. Zima, L. Beneš, Langmuir 18 (2002) 1211-1217.

[12] L. Beneš, K. Melánová, V. Zima, J. Kalousová, J. Votinský, Inorg. Chem. 36 (1997) 2850-2854.

[13] Joint Committee on Powder Diffraction Standards, International Centre of Diffraction Data, Swarthmore, PA.

[14] K. Melánová, L. Beneš, V. Zima, R. Vahalová, M. Kilián, Chem. Mater. 11 (1999) 2173-2178. 